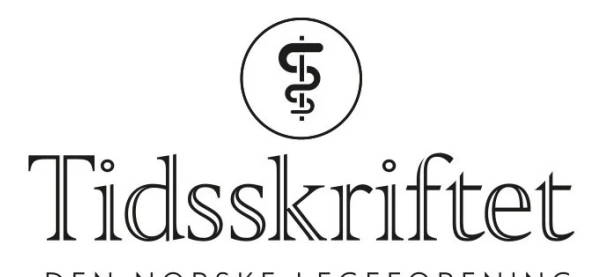

DEN NORSKE LEGEFORENING

\title{
Hva er forventet levealder?
}

MEDISIN OG TALL

JON MICHAEL GRAN

j.m.gran@medisin.uio.no

Jon Michael Gran er førsteamanuensis i biostatistikk ved Universitetet i Oslo.

Forfatteren har fylt ut ICMJE-skjemaet og oppgir ingen interessekonflikter.

\section{MATS JULIUS STENSRUD}

Mats Julius Stensrud er lege og førsteamanuensis i biostatistikk ved École polytechnique fédérale de Lausanne (EPFL) i Sveits.

Forfatteren har fylt ut ICMJE-skjemaet og oppgir ingen interessekonflikter.

Det er vanlig å bruke forventet levealder til å beskrive endringer i overlevelse over tid eller forskjeller i overlevelse mellom populasjonsgrupper, men fortolkningen av denne størrelsen er subtil. For å forstå fortolkningen, må vi forstå hvordan tallene beregnes.

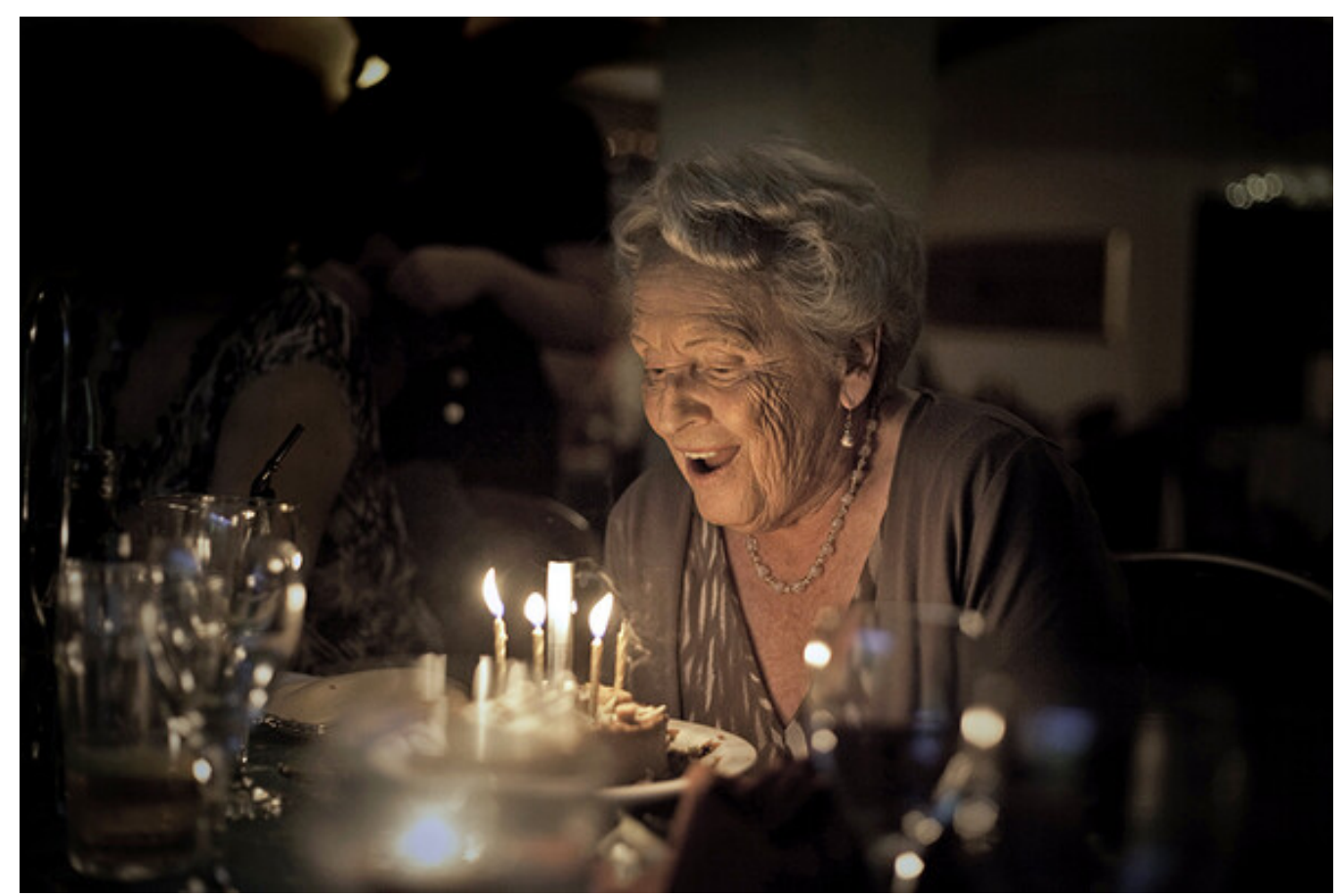


Illustrasjon: nicolamargaret/iStock

I 2020 var forventet levealder i Norge 84,9 år for kvinner og 81,5 år for menn (1). I en artikkel i The BMJ ble det nylig rapportert at forventet levealder i flere andre vestlige land har falt som følge av covid-19 (므). Hvordan skal vi tolke disse estimatene?

\section{Estimering av forventet levealder}

Anta at vi er interessert i forventet levealder for et 2020-barn. Ideelt sett hadde vi beregnet denne levealderen ved å vente til alle var døde og så beregnet gjennomsnittlig levetid (den såkalte kohortmetoden). En slik fremgangsmåte krever lang oppfølging og er ikke spesielt hensiktsmessig. Hvis man vil beregne forventet levealder på en annen måte, må man gjøre antagelser og modellvalg. I slike beregninger brukes vanligvis aldersbestemte dødsrater i en gitt periode, la oss si 2020, og så antar man at 2020-barn vil bli utsatt for 2020dødeligheten i hvert alderstrinn gjennom livet (periodemetoden). Dette estimatet på forventet levetid er derfor et øyeblikksbilde, ikke en fremskrivning.

Problemet med periodemetoden er at dødeligheten vi så i 2020, for eksempel under pandemien i Italia eller USA, neppe vil gjelde de neste tiårene. Derfor er det misvisende å kalle dette forventet levealder. Estimatet gjelder en høyst hypotetisk kohort som er av liten praktisk interesse. Hvis man er interessert i endring i dødelighet som følge av covid-19, er såkalt overdødelighet (3) ofte et bedre mål. Selv i «vanlige» år, uten covid-19, har det blitt vist at den klassiske måten å beregne forventet levealder på kan underestimere reell levealder med så mye som ti år $(4,5)$.

\section{Forskjeller i individuell heterogenitet}

På samme måte som man beregner forventet levealder fra fødsel, kan man også beregne forventet gjenværende levealder, gitt at en bestemt alder er nådd. For eksempel kan forventet gjenværende levetid ved ett års alder i prinsippet være høyere enn ved null år i land med veldig stor barnedødelighet. Når man betinger på overlevelse, studerer man en ny populasjon av individer. Høy dødelighet i det første leveåret kan påføre en seleksjon av barn med gode forutsetninger for overlevelse. Denne seleksjonen kan føre til at de som er i live etter ett år (i gjennomsnitt), har bedre forutsetninger enn man ville sett hvis barnedødeligheten var lavere. I ulike land og områder kan barnedødeligheten være forskjellig, og det kan føre til ulik seleksjon. Dette er en av grunnene til at det å sammenlikne og tolke forskjeller i forventet levealder er utfordrende.

Forskjeller i estimert forventet levealder mellom land brukes som argument for å promotere alt fra helsetjenester til kosthold i landene som kommer best ut. Dette er problematisk. Land som har hatt en rask bedring i levekår, kan ha en eldre populasjon med god underliggende helse på grunn av en seleksjon som ligger lang tilbake i tid. Japan og Italia hadde i 2014 høyere forventet levealder enn Norge. Hvis man derimot velger ut en bestemt fødselskohort, for eksempel de som ble født i 1950, og ser på gjennomsnittlig antall tapte leveår i en bestemt periode, for eksempel frem til 2010, snus bildet (므).

\section{Arbeidsliv}

Forventet levealder brukes også til å studere andre helseutfall enn død. I studier av sykefravær er man for eksempel interessert i forventet tid i arbeidslivet (7.). Både sykefravær og arbeidsmarked kan være preget av store svingninger over tid, og derfor møter vi mange av de samme utfordringene her som i tolkningen av endring i estimert levealder under covid-19-pandemien. Det er lite trolig at dagens rater for sykemelding, uførhet og arbeidsledighet holder seg uforandret i fremtiden. Derfor kan ikke ratene for 5o-åringer i 2015 brukes som et plausibelt estimat for dem som vil fylle 50 år i 2035.

\section{Konklusjon}


Størrelsen man vanligvis kaller forventet levealder, har fått et misvisende navn. Ofte er andre mål mer relevante, som antall tapte leveår opp til en viss alder, estimert ved kohortmetoden. Skal man fremskrive reell forventet levealder, må man i det minste gjøre velfunderte antagelser om fremtidige dødsrater.

\section{LITTERATUR}

1. Bævre K. Forventet levealder i Norge. Folkehelserapporten [oppdatert 8.7.2021]. https://www.fhi.no/nettpub/hin/samfunn/levealder/ Lest 9.12.2021.

2. Islam N, Jdanov DA, Shkolnikov VM et al. Effects of covid-19 pandemic on life expectancy and premature mortality in 2020: time series analysis in 37 countries. BMJ 2021; 375: eo66768. [PubMed] [CrossRef]

3. Modi C, Böhm V, Ferraro S et al. Estimating covid-19 mortality in Italy early in the covid-19 pandemic. Nat Commun 2021; 12: 2729. [PubMed][CrossRef]

4. Goldstein JR, Wachter KW. Relationships between period and cohort life expectancy: gaps and lags. Popul Stud 2007; 6o: 257-69. [PubMed][CrossRef]

5. Hansen MF, Stephensen P. Danmarks fremtidige befolkning. Befolkningsfremskrivning 2013. København: DREAM, 2013. https://dreamgruppen.dk/media/10640/r2013_01.pdf Lest 9.12.2021.

6. Borgan $\emptyset$, Keilman N. Do Japanese and Italian women live longer than women in Scandinavia? Eur J Popul 2019;35: 87-99. [PubMed][CrossRef]

7. Robroek SJ, Nieboer D, Järvholm B et al. Educational differences in duration of working life and loss of paid employment: working life expectancy in The Netherlands. Scand J Work Environ Health 2019; 46: 77-84. [PubMed][CrossRef]

Publisert: 14. februar 2022. Tidsskr Nor Legeforen. DOI: 10.4045/tidsskr.21.0828

(C) Tidsskrift for Den norske legeforening 2023. Lastet ned fra tidsskriftet.no 26. april 2023. 